\title{
Study on the physico-chemical properties, sensory attributes and shelf life of pineapple powder incorporated biscuits
}

\author{
M. Thivani, T. Mahendran ${ }^{1}$ and M. Kanimoly ${ }^{2}$ \\ Department of Agricultural Chemistry, Faculty of Agriculture, Eastern University, Sri Lanka \\ Correspondence: ${ }^{1}$ thevamahen@yahoo.com² kanimolym@yahoo.com
}

Received: $5^{\text {th }}$ September 2016, Revised: $26^{\text {th }}$ November 2016, Accepted: $21^{\text {st }}$ December 2016

\begin{abstract}
The bakery industry is growing very fast and the products are becoming increasingly popular among consumers world-wide. Among ready-to-eat snacks, biscuits possess several attractive features including wider consumption base, relatively long shelf-life and preferred eating quality. Pineapples constitute important natural and valuable material in producing functional foods due to the presence of several anti-oxidants and bioactive compounds. Therefore, the aim of the present study was to investigate the nutritional composition and sensory quality of wheat flour biscuits incorporated with pineapple powder at the rates of $3,5,10$, and $15 \%$ (w/w basis). The protein, fat, total sugar, moisture and mineral contents were significantly $(p<0.05)$ changed during storage. Nutritional analysis indicated that biscuits incorporated with $5 \%$ pineapple powder had a slow rate of increase in moisture content (4.19 to $5.0 \%)$ and decreasing trend in protein $(22.15$ to $22.06 \%$ ), fat (18.83 to $18.79 \%$ ), total sugar ( 58.52 to $58.34 \%$ ) and mineral contents ( 2.212 to $1.591 \%$ ) compared to other treatments during storage. Among the treatments, the biscuits prepared with 5\% pineapple powder had the highest nutritional and sensory quality, having the overall acceptability score of 7.7 in a 9-point hedonic scale. The shelf life evaluation showed that these biscuits could be stored for 6 weeks at the ambient conditions of average temperature at $30 \pm 1^{\circ} \mathrm{C}$ and $\mathrm{RH}$ at 75 $80 \%$ with acceptable quality.
\end{abstract}

Keywords: Biscuits, physico-chemical properties, pineapple powder, sensory attributes, shelf life

\section{Introduction}

Biscuits, which are leavened baked products, are one of the most delicious foods preferred by most people. Biscuits represent the largest category of snack item among bakery products (Pratima and Yadav, 2000). They are stable foods and have advantages such as ready-to-eat form, wide 
consumption, long shelf life and eating quality (Siddiqui and Nasreen, 2014). Biscuits are widely accepted and consumed by almost all profiles of consumers in many countries and therefore offer a valuable supplementation vehicle for nutritional improvement (Arshad et al., 2007). Currently, cookies are prepared from composite flour or fortified with some other good sources of nutrients (Wani et al., 2015). Modifications of basic recipes and incorporation of new ingredients such as fibers, fat replacers, cereals other than wheat, etc. have led to novel biscuit formulations with improved functionality and nutritive value (Handa et al., 2012; Yadav et al., 2012).

Fruits are produced in considerable quantities and consumed locally, but are seldom processed in order to add value. Fruits exhibit relatively high metabolic activity compared with other plant derived foods such as seeds and tubers. These metabolic activities continue after harvesting, thus making most fruits highly perishable commodities (Offia-Olua and Ekwunife, 2015). Therefore, there is need for diversity in commercial utilization of fruits into different forms. There are numerous ways of utilizing and processing fruits such as processing into juice, jams, concentrates, jellies and dehydrated products. The introduction of fruit based composite flour is novel, as recently, fruits and vegetables have received much attention as a source of biologically active substances because of their anti-oxidant, anti-carcinogenic and antimutagenic properties (Tortoe et al., 2014). Pineapple (Ananas comosus) is cultivated in the tropical and subtropical regions of the world and is well known for its attractive sensorial and nutritional characteristics. Further, it is a good source of carotene and ascorbic acid and rich in vitamin $\mathrm{B}_{1}$; it is also containing carbohydrate, protein, fiber, calcium and iron (Ade et al., 2015).

Fresh pineapple is often expensive because of its delicate nature. Pineapples continue to ripen at appropriate temperatures after harvesting. The shelf life of ripe pineapple is short and limited to 4-6 days (Kadam et al., 2012 ) and the average yield of processing ranges from $45-55 \%$. Therefore, an alternate solution is the development of a pineapple powder from pineapple pulp as a value added ingredient for the bakery and confectionary industries (Deliza et al., 2005). Pineapple is commonly found in Sri Lankan market and is being consumed raw and also processed into various food products, including jam, jellies, juices, puree, powder and nectar. Pineapple fruit is used for the preparation of pineapple powder because of difficulty in ready consumption as fresh due to their big size, hardy nature and also to prevent postharvest losses. Production of biscuits incorporated with pineapple powder lead to innovations in new product development. Therefore, the objective of the present study was to develop pineapple powder incorporated biscuits and to assess the physico-chemical properties and sensory attributes in the formulated biscuits during storage at ambient conditions. 


\section{Materials and Methods}

\subsection{Preparation of pineapple powder}

Fully ripe and fresh pineapples (Variety: Mauritius) were selected, washed, peeled and their thorny eyes were removed. They were sliced lengthwise; each slice was cut into $2 \mathrm{~cm}$ thickness. The slices were dipped in to the potassium metabisulphite solution $(0.02 \%)$ for 5 minutes to prevent discoloration. These slices were placed in a single layer on stainless steel trays. The vacuum oven (Model DZF 6020-W, Optima, India) was pre-heated to $70^{\circ} \mathrm{C}$, and the trays were loaded. The oven temperature was maintained at $60^{\circ} \mathrm{C}$. Fruit slices were dried for $12-14 \mathrm{~h}$ until the slices became leathery and not sticky. The dried slices were milled using hammer mill (Model: DY-19, Spain) and sieved into particle size of $100 \mu \mathrm{m}$ using a stainless steel double sieve (PRO-100, China). The pineapple powder was packed and stored in a glass bottle at ambient conditions for subsequent use in the study.

\subsection{Formulation of Pineapple powder incorporated biscuit}

Biscuits were prepared using creamery method for making biscuit dough (Manley, 2011). Hydrogenated fat (Margarine 50g) and powdered sugar $(175 \mathrm{~g})$ were creamed together by electric beater (GHM-05, Zhejiang, China). All-purpose flour (225 g) and baking powder ( $3 \mathrm{~g}$ ) were sieved twice together. Sieved flour was added to creamed paste. Different amount of pineapple powder was incorporated to produce the following treatments:

$\mathrm{T}_{1}: 3 \%$ of pineapple powder (3g pineapple powder/100g mixture)

$\mathrm{T}_{2}: 5 \%$ of pineapple powder (5g pineapple powder $/ 100 \mathrm{~g}$ mixture)

$\mathrm{T}_{3}: 10 \%$ of pineapple powder (10g pineapple powder $/ 100 \mathrm{~g}$ mixture)

$\mathrm{T}_{4}: 15 \%$ of pineapple powder (15g pineapple powder $/ 100 \mathrm{~g}$ mixture)

Firm dough was prepared with each mixture. The dough were rolled out to $2.5 \mathrm{~mm}$ thickness and cut into round pieces having $5 \mathrm{~cm}$ diameter which were placed on oiled stainless steel trays and baked in a pre-heated oven (Model: PER 1700 , China) at $150^{\circ} \mathrm{C}$ for 4 min to produce biscuits.

\subsection{Determination of physico-chemical properties}

The nutritional properties such as protein, fat, total sugar, moisture and mineral contents of pineapple powder incorporated biscuits were analyzed according to the standard method as described by AOAC (2002). All analyses were carried out in triplicates. 


\subsection{Evaluation of sensory attributes}

Sensory evaluation was carried out using a trained panel of thirty members consisting equal men and women. Samples of biscuit were presented to each of the panelist and were asked to assess the taste, colour, texture, crispness, pineapple flavour, absence of off flavour and overall acceptability using ninepoint hedonic scale with 1 representing the least score (dislike extremely) and 9 the highest score (like extremely). The sensory evaluation was carried out either at $10 \mathrm{am}$ for the morning session and at $3 \mathrm{pm}$ for the afternoon session to get accurate results. The analysis was performed for the freshly made biscuits and at the end of the storage period.

\subsection{Determination of shelf life}

The pineapple biscuits were packed in laminated plastics materials (Metabolic, MA 18240, USA) and stored at the ambient conditions of average temperature at $30^{\circ} \pm 1^{\circ} \mathrm{C}$ and $\mathrm{RH}$ at $75-80 \%$ for 6 weeks. The biscuits were assessed for the quality characteristics during the storage period at two week intervals. Visual observations were made daily to evaluate the microbial spoilage and to determine the shelf life of the biscuits.

\subsection{Statistical analyses}

The experiment was conducted using Completely Randomized Design, consisting of four treatments replicated three times. Data were subjected to Analysis of Variance (ANOVA) and means were separated using Duncan's Multiple Range Test at $p<0.05$ by using Statistical Analysis System (SAS 9.1 Version, North Carolina, USA) software statistical package. The mean scores of the sensory evaluation were tested using analysis of variance (ANOVA) method and differences were separated by Friedman test.

\section{Results and Discussion}

\subsection{Nutritional composition of pineapple powder}

The nutritional composition of the pineapple powder was moisture 6.07\%, titrable acidity $0.64 \%$ (as citric acid), ascorbic acid $57.2 \mathrm{mg} / 100 \mathrm{~g}$, total sugar $12.8 \%$, fiber $0.47 \%$ and total soluble solids $13.2 \%$. The values are in accordance with Rodgers et al. (2007). According to Kadam et al. (2012) nutritional composition of pineapple powder however depends on the variety, maturity, size of the fruit, harvesting interval and climatic conditions of the growing area. 


\subsection{Physico-chemical characteristics of pineapple Powder incorporated biscuits}

The nutritional analysis indicated that all the biscuits contained favourable proportion of protein, fat, total sugars, moisture and mineral contents. Substitution of pineapple powder for wheat flour improves the nutritive value of the product. There was a decrease in protein, fat, total sugars and mineral contents while increases in moisture level were observed in pineapple powder incorporated biscuits during storage.

\subsubsection{Protein Content}

The data for changes in protein content of biscuits, during storage under ambient condition are shown in Fig. 1. Typically, all-purpose wheat flour contains 9.5 to $11.5 \%$ protein. According to the results, the protein content decreased significantly $(p<0.05)$ through the storage period. This may occur due to interaction between reducing sugars and amino acids (maillard reaction) and it is a major cause of quality change and degradation of nutritional level of many foods.

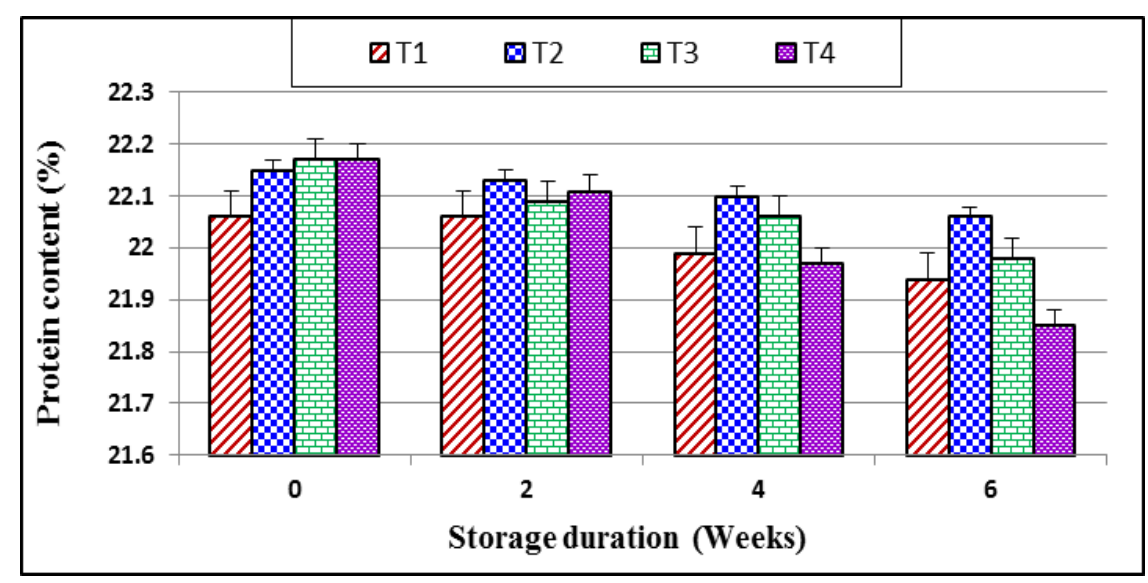

Fig. 1: Changes in protein content of pineapple powder incorporated biscuits during Storage. (Values are means of triplicates; Vertical bars indicate the standard errors; $\mathbf{T}_{1}: 3 \mathrm{~g}$ pineapple powder/100 $\mathrm{g}$ mixture; $\mathbf{T}_{2}: 5 \mathrm{~g}$ pineapple powder/100 $\mathrm{g}$ mixture; $\mathbf{T}_{3}: 10 \mathrm{~g}$ pineapple powder/100 g mixture; $\mathbf{T}_{4}: 15 \mathrm{~g}$ pineapple powder/100 $\mathrm{g}$ mixture)

Maillard reaction impairs with the nutritional value of protein and also this reaction results in the loss of protein solubility and stability (Fennema, 1996). Treatment 2 ( $5 \%$ pineapple powder incorporated biscuits) had a lower rate of decreasing trends of protein from 22.15 to $22.06 \%$ compared to the other 
treatments. Various proteins present in wheat flour can undergo changes such as protein cross-linking, protein-carbohydrate interactions and denaturing of protein during processing (Singh, 2000).

\subsubsection{Fat Content}

The fat content decreased significantly $(p<0.05)$ throughout the storage period (Table 1). Treatment 2 (5\% pineapple powder added to $100 \mathrm{~g}$ mixture) had a lowest rate of decreasing trend in fat than other treatments. This may be due to low initial moisture content in the biscuits. Reduction in fat content was due to the oxidation of unsaturated fatty acids with the atmospheric oxygen and moisture uptake during storage (Brooker, 1998).

Table 1: Changes in Fat Content (\%) of Pineapple Powder incorporated Biscuits during Storage

\begin{tabular}{ccccc}
\hline \multirow{2}{*}{ Treatments } & \multicolumn{4}{c}{ Storage duration (weeks) } \\
\cline { 2 - 5 } & \multicolumn{1}{c}{$\mathbf{0}$} & $\mathbf{2}$ & $\mathbf{4}$ & $\mathbf{6}$ \\
\cline { 2 - 5 } $\mathrm{T}_{1}$ & $18.77 \pm 0.07^{\mathrm{b}}$ & $18.72 \pm 0.08^{\mathrm{c}}$ & $18.64 \pm 0.08^{\mathrm{c}}$ & $18.57 \pm 0.30^{\mathrm{c}}$ \\
$\mathrm{T}_{2}$ & $18.83 \pm 0.03^{\mathrm{a}}$ & $18.82 \pm 0.03^{\mathrm{a}}$ & $18.81 \pm 0.03^{\mathrm{a}}$ & $18.79 \pm 0.03^{\mathrm{a}}$ \\
$\mathrm{T}_{3}$ & $18.82 \pm 0.06^{\mathrm{a}}$ & $18.80 \pm 0.03^{\mathrm{b}}$ & $18.78 \pm 0.03^{\mathrm{b}}$ & $18.74 \pm 0.02^{\mathrm{ab}}$ \\
$\mathrm{T}_{4}$ & $18.83 \pm 0.03^{\mathrm{a}}$ & $18.8 \pm 0.03^{\mathrm{b}}$ & $18.76 \pm 0.03^{\mathrm{b}}$ & $18.72 \pm 0.08^{\mathrm{b}}$ \\
\hline
\end{tabular}

Values are means of triplicates \pm Standard error.

Means values with the same superscript letters in the same column are not significantly different from each other at $\mathrm{P}=5 \%$ by DMRT.

Fat and oil contribute to the tenderization of baked products through inhibition of gluten development and starch gelatinization (Patrignani et al., 2014). This is through a water proofing effect, possibly due to complexion with carbohydrate and/or protein. According to O'Brien et al., (2003), the reduction of fat content in the biscuits during storage is due to the autooxidation of unsaturated fatty acids in the lipids.

\subsubsection{Total Sugar Content}

The total sugars content of the biscuits decreased significantly $(p<0.05)$ throughout the storage period (Table: 2), due to the thermal degradation of sugars during baking and sugar polymerization during storage. Treatment 2 (5\% pineapple powder added biscuits) showed reduced rate of a decreasing trend compared to the other treatments. It had higher sugar content at the end 
of the storage period possibly due to the low moisture gain and reduced complex reaction with sugars.

Table 2: Changes in total sugar content (\%) of pineapple powder incorporated biscuits during storage.

\begin{tabular}{ccccc}
\hline \multirow{2}{*}{ Treatments } & \multicolumn{4}{c}{ Storage duration (weeks) } \\
\cline { 2 - 5 } & $\mathbf{0}$ & $\mathbf{2}$ & $\mathbf{4}$ & $\mathbf{6}$ \\
\cline { 2 - 5 } $\mathrm{T}_{1}$ & $58.34 \pm 0.08^{\mathrm{b}}$ & $58.34 \pm 0.28^{\mathrm{d}}$ & $58.25 \pm 0.34^{\mathrm{d}}$ & $58.16 \pm 0.13^{\mathrm{d}}$ \\
$\mathrm{T}_{2}$ & $58.52 \pm 0.10^{\mathrm{a}}$ & $58.52 \pm 0.23^{\mathrm{b}}$ & $58.41 \pm 0.27^{\mathrm{a}}$ & $58.34 \pm 0.16^{\mathrm{a}}$ \\
$\mathrm{T}_{3}$ & $58.53 \pm 0.06^{\mathrm{a}}$ & $58.53 \pm 0.13^{\mathrm{c}}$ & $58.36 \pm 0.13^{\mathrm{c}}$ & $58.21 \pm 0.29^{\mathrm{c}}$ \\
$\mathrm{T}_{4}$ & $58.61 \pm 0.07^{\mathrm{a}}$ & $58.61 \pm 0.09^{\mathrm{a}}$ & $58.22 \pm 0.33^{\mathrm{b}}$ & $58.12 \pm 0.18^{\mathrm{b}}$ \\
\hline
\end{tabular}

Values are means of triplicates \pm Standard error.

Means values with the same superscript letters in the same column are not significantly different from each other at $\mathrm{P}=5 \%$ by DMRT.

\subsubsection{Moisture Content}

The study showed that the moisture content of the biscuits significantly $(p<0.05)$ increased during storage (Fig. 2). Biscuits are very hygroscopic and have an equilibrium relative humidity around $30 \%$. Therefore, in most cases the biscuits must be protected from the atmosphere to prevent or at least reduce, moisture pick up from the atmosphere. Treatment $2(5 \%$ pineapple powder incorporated biscuits) had the lowest rate of increasing in moisture content from 4.19 to $5.0 \%$ compared to other treatments.

The moisture gains of biscuits occurred due to water vapour transmission from the storage environment as the biscuits are very hygroscopic and the moisture absorption from the water vapor present in the air inside the package. Another possibility of the moisture increase could be through air intake from the package seal (Kumar et al., 2016). Biscuits with low moisture content will have longer shelf life if they are stored under control conditions such as appropriate packaging which is impervious to moisture and gasses (Bertagnolli et al., 2014). Our results are in contrast with the findings of Sindurani et al. (2000) who reported that the moisture content of value-added cookies decreased during storage at ambient conditions. The different directions of values may be due to the different packaging materials, methodologies and conditions used for storage of cookies. 


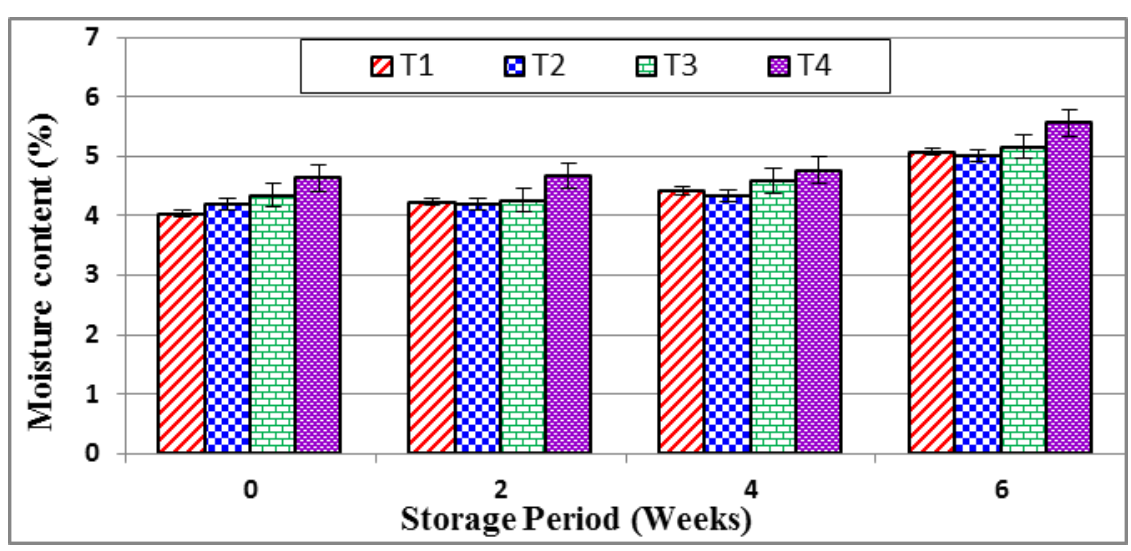

Fig. 2: Changes in Moisture Content of Pineapple Powder incorporated Biscuits during Storage (Values are means of triplicates; Vertical bars indicate the standard errors; $\left(\mathbf{T}_{1}: 3 \mathrm{~g}\right.$ pineapple powder $/ 100 \mathrm{~g}$ mixture; $\mathbf{T}_{2}: 5 \mathrm{~g}$ pineapple powder $/ 100 \mathrm{~g}$ mixture; $\mathbf{T}_{3}: 10 \mathrm{~g}$ pineapple powder $/ 100 \mathrm{~g}$ mixture; $\mathbf{T}_{4}: 15 \mathrm{~g}$ pineapple powder $/ 100 \mathrm{~g}$ mixture)

\subsubsection{Mineral Content}

Mineral content decreased significantly $(p<0.05)$ during the storage of biscuits (Table: 3). Minerals in all treatments have undergone very little changes and the treatment 2 (5\% pineapple powder added biscuits) had a very slower rate of decreasing trend compared to other treatments.

Table 3. Changes in Mineral Content (\%) of Pineapple Powder incorporated Biscuits during Storage

\begin{tabular}{ccccc}
\hline Treatments & \multicolumn{4}{c}{ Storage duration (weeks) } \\
\cline { 2 - 5 } & $\mathbf{0}$ & $\mathbf{2}$ & $\mathbf{4}$ & $\mathbf{6}$ \\
\cline { 2 - 5 } $\mathrm{T}_{1}$ & $2.116 \pm 0.027^{\mathrm{d}}$ & $2.209 \pm 0.04^{\mathrm{c}}$ & $2.060 \pm 0.025^{\mathrm{b}}$ & $1.500 \pm 0.010^{\mathrm{c}}$ \\
$\mathrm{T}_{2}$ & $2.212 \pm 0.032^{\mathrm{c}}$ & $2.201 \pm 0.06^{\mathrm{b}}$ & $2.186 \pm 0.02^{\mathrm{a}}$ & $1.591 \pm 0.005^{\mathrm{a}}$ \\
$\mathrm{T}_{3}$ & $2.223 \pm 0.011^{\mathrm{b}}$ & $2.205 \pm 0.03^{\mathrm{b}}$ & $2.174 \pm 0.02^{\mathrm{a}}$ & $1.569 \pm 0.005^{\mathrm{b}}$ \\
$\mathrm{T}_{4}$ & $2.234 \pm 0.017^{\mathrm{a}}$ & $2.230 \pm 0.01^{\mathrm{a}}$ & $2.176 \pm 0.034^{\mathrm{a}}$ & $1.576 \pm 0.012^{\mathrm{b}}$ \\
\hline
\end{tabular}

Values are means of triplicates \pm standard error. Means with the same superscript letters in the same column are not significantly different from each other at $\mathrm{P}=5 \%$ by DMRT 
Mineral losses can occur by heat-induced chemical reaction between reducing sugars and amino acids and/or proteins to form compounds that bind minerals (Passos et al., 2013). These reaction products are more resistant to digestion and hence capable of having their mineral-binding properties to remain intact. Considerable amounts of some soluble minerals are dissolved in water and leads to mineral loss during processing and storage due to hygroscopic nature of the product.

\subsection{Sensory analysis of Pineapple Powder incorporated Biscuits during Storage}

The sensory scores of the pineapple biscuits during storage is shown in Fig. 3. The results revealed that there were significant $(p<0.05)$ differences among the treatments on the sensory characteristics such as taste, colour, texture, crispiness, pineapple flavour, absence of off flavor and overall acceptability at $5 \%$ significance level. Organoleptic characteristics of biscuits have slightly changed during the storage period. This may be due to non-enzymatic browning reaction (maillard reaction) and auto-oxidation of fats.

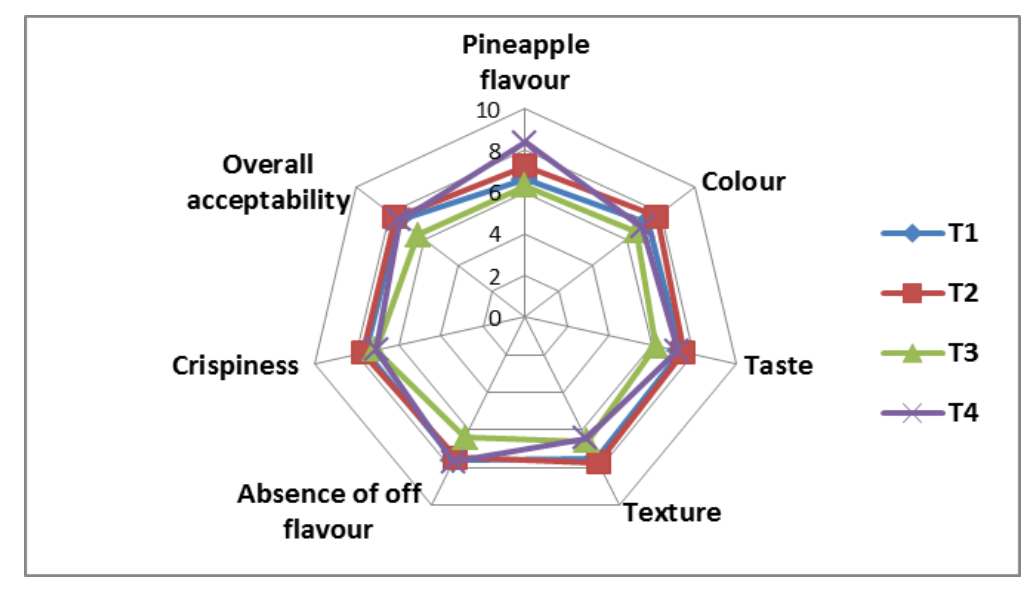

Fig. 3 Sensory scores of Pineapple powder incorporated Biscuits during storage ( $\mathbf{T}_{1}: 3 \mathrm{~g}$ pineapple powder $/ 100 \mathrm{~g}$ mixture; $\mathbf{T}_{2}: 5 \mathrm{~g}$ pineapple powder $/ 100 \mathrm{~g}$ mixture; $\mathbf{T}_{3}: 10 \mathrm{~g}$ pineapple powder $/ 100 \mathrm{~g}$ mixture; $\mathbf{T}_{4}: 15 \mathrm{~g}$ pineapple powder $/ 100 \mathrm{~g}$ mixture)

The biscuits incorporated with $5 \%$ pineapple powder $\left(\mathrm{T}_{2}\right)$ had the highest overall acceptability characteristics based on the physic-chemical and organoleptic point of view when compared to other treatments. From the overall acceptability rating, the $5 \%$ pineapple powder added biscuits had the highest mean value of 7.7 in a 9-point hedonic scale and no significant $(p>0.05)$ changes in organoleptic characters were observed up to 6 
weeks of storage in ambient condition of average temperature at $30^{\circ} \pm 1^{\circ} \mathrm{C}$ and relative humidity of $75-80 \%$. Similar results were reported by Ade et al. (2015) in which addition of 5\% dried pineapple pulp is feasible in producing nutritionally and organoleptically acceptable biscuits.

\subsection{Conclusions}

Incorporation of pineapple powder into wheat flour for the production of biscuits is possible based on the physico-chemical properties and sensory quality of the biscuits. The results revealed that the 5\% pineapple powder incorporated biscuits had the highest overall quality during the storage compared to other treatment combinations. Therefore, the $5 \%$ pineapple powder added biscuits could be stored for 6 weeks at the ambient condition of $30 \pm 1^{\circ} \mathrm{C}$ and $75-80 \% \mathrm{RH}$ without any significant changes in quality characteristics.

\section{References}

Ade KD, Lal A, Mishra AA. 2015. Development and Quality evaluation of Pineapple pomace and Wheat bran fortified biscuits. The Allahabad Farmer Journal 70(2): 92-97.

AOAC. 2002. Official Methods of Analysis. (17 $7^{\text {th }}$ Edition). Association of Official Analytical Chemists. Washington, USA.

Arshad MU, Anjum FM, Zahoor T. 2007. Nutritional assessment of cookies supplemented with defatted wheat germ. Food Chemistry 102: 123-128.

Bertagnolli SMM, Silveira MLR, Fogaça ADO, Umann L, Penna NG. 2014. Bioactive compounds and acceptance of cookies made with Guava peel flour. Journal of Food Science and Technology 34: 303-308.

Brooker B. 1998. The role of fat in biscuits: Strategy for fat reducing products. Woodhead Publishers, Cambridge, UK 127-168 pp.

Deliza R, Rosenthal A, Abadio FBD, Silva CHO, Castillo C. 2005. Application of high pressure technology in the fruit juice processing: benefits perceived by consumers. Journal of Food Engineering 67: 241-246.

Fennema OR. 1996. Food Chemistry. CRC press, Wisconsin, USA, 157-412 pp.

Handa C, Goomer S, Siddhu A. 2012. Physico-chemical properties and sensory evaluation of fructoligosaccharide enriched cookies. Journal of Food Science and Technology 49(2): 192-199.

Kadam DM, Wilson RA, Kaur V, Chadha S, Kaushik P, Kaur, Rai DR. 2012. Physicochemical and microbial quality evaluation of foam-mat-dried pineapple powder. International Journal of Food Science and Technology 47(8): 1654-1659.

Kumar R, Samsher, Chandra S. 2016. Studies on the proximate analysis of biscuits using multigrain flours during ambient condition. International Journal of Food Science and Nutrition 1(2):39-41.

Manley D (Ed.). 2011. Manley's technology of bakery products: Biscuits, crackers and cookies. Elsevier, USA. 234-249 pp. 
O'Brien CM, Chapman D, Neville DP, Keogh MK, Arendt EK. 2003. Effect of varying the micro-encapsulation process on the functionality of hydrogenated vegetable fat in short dough biscuits. Food Research International 36(3): 215-221.

Offia-Olua BI, Ekwunife OA. 2015. Production and evaluation of the physico-chemical and sensory qualities of mixed fruit leather produced from apple (Musa pumila), banana (Musa sapientum), pineapple (Ananas comosus). Nigerian Food Journal 33(1): 22-28.

Passos MEAD, Moreira CFF, Pacheco MTB, Takase I, Lopes MLM, Valente-Mesquita VL. 2013. Proximate and mineral composition of industrialized biscuits. Food Science and Technology 33(2): 323-331.

Patrignani M, Conforti PA, Lupano CE. 2014. The role of lipid oxidation on biscuit texture during storage. International Journal of Food Science and Technology 49(8):1925-1931.

Pratima A, Yadave MC. 2000. Effect of incorporation of liquid dairy by-product chemical characteristic of soy fortified biscuits during storage. Journal Food Science and Technology 37:158-161.

Rodgers GL, Bhangale NJ, Robert S. 2007. Quality evaluation of pineapple powder fortified crackers during storage. Indian Food Packer 48: 47-55.

Siddiqui AA, Nasreen L. 2014. Effects of the baking temperature and time on the quality of biscuits. Journal of State University of Bangladesh 5(1): 1-12.

Singh RP 2000. Scientific principles of shelf life evaluation protein biscuits. Journal of Food Science and Technology 31: 117-121.

Sindurani JA, Smith JL, Rajmohan T. 2000. Effects of different levels of fruit powders on the storage stability of value-added cookies. Indian Journal of Food Science and Technology 44(1): 97-100.

Tortoe C, Johnson PT, Slaghek T, Oduro-Yeboah C, Addo P, Nyarko A, Tamakloe I. 2014. Physico-chemical, proximate and sensory properties of organic side-stream pineapple (Ananas sp.) flour. International Journal of Food Science, Nutrition and Engineering 4(1): 1-8.

Wani SH, Gull A, Allaie F, Safapuri TA. 2015. Effects of incorporation of whey protein concentrate on physic-chemical, texture, and microbial evaluation of developed cookies Cogent Food and Agriculture. 1(1): 109-116.

Yadav RB, Dhull N, Yadav BS. 2012. Effect of incorporation of plantain and chickpea flours on the quality characteristics of biscuits. Journal Food Science and Technology 49(2): 207-213. 